\title{
Az ingázásból származó ökológiai lábnyom csökkentésének lehetôségei a közösségi gazdaság révén a budapesti városrégióban
}

\section{A Budapest körül zajló szuburbanizáció és városi szétterülés, valamint} a munkahelyek elővárosi centrumokba települése az ezredforduló óta az ingázás és a hozzá kapcsolódó jármüforgalom jelentős növekedését hozta magával. A szerzők arra keresik a választ, hogy a közösségi gazdaság nyújtotta alternatív közlekedési lehetőségek - az autómegosztó és a telekocsi szolgáltatások - milyen jelentőséggel bírnak az ingázásban, s milyen szerepet játszhatnak a városrégió ökológiai lábnyomának csökkentésében.

DOI 10.24228/KTSZ.2019.2.5

\author{
Szigeti Cecília \\ Széchenyi István Egyetem \\ Nemzetközi és Elméleti Gazdaságtan Tanszék \\ E-mail: szigetic@sze.hu
}

\section{Kovács Zoltán}

MTA CSFK

Földrajztudományi Intézet;

Szegedi Tudományegyetem

Gazdaság- és Társadalomföldrajz Tanszék

E-mail: zkovacs@iif.hu

\author{
Egedy Tamás \\ MTA CSFK \\ Földrajztudományi Intézet \\ E-mail: egedy@gmx.net
}

\author{
Szabó Balázs \\ MTA CSFK \\ Földrajztudományi Intézet \\ E-mail: szbazs@gmail.com
}

\section{BEVEZETÉS}

A társadalmi fejlődés a városi környezetben újabb és újabb viselkedési modelleket generál az élet minden területén, ideértve a munka, a szabadidős és a kulturális tevékenységeket. Ez a fejlődés természetesen számos konfliktushelyzetet hordoz. Az egyik ilyen terület a városi mobilitás, amely elengedhetetlen a társadalmi fejlődéshez, ugyanakkor számos érdeksérelemmel is együtt jár (Bessenyei 2014).
Napjainkban a nagyvárosi élet egyik legfőbb kihívása a közlekedés megszervezése, a népesség napi mozgásának biztosítása a lakóhely, a munkahely és a szolgáltatások között. A metropolizáció folyamatával és a városok szétterülésével (urban sprawl) párhuzamosan egyre nagyobb nehézségekbe ütközik a közlekedés fenntartása és lebonyolítása a nagyvárosi régiókban, miközben az idő és az elérhetőség egyre inkább felértékelődnek. $\mathrm{Az}$ elmúlt évtizedben a forgalomszervezési, 
logisztikai problémák mellett a környezeti kihívások és konfliktusok is a figyelem középpontjába kerültek, s egyre több kutatás célozza a közlekedés - elsősorban a gyorsan növekvő ingázás - természeti környezetre gyakorolt hatásait. A kutatások egy jól körülhatárolható köre az ökológiai lábnyom oldaláról közelíti meg a kérdést. Az ökológiai lábnyom mérőszám azt fejezi ki, hogy adott technológiai fejlettség mellett egy emberi közösségnek milyen mennyiségű produktív földterületre van szüksége önmaga fenntartásához és a megtermelt hulladék elnyeléséhez (mértékegysége a világátlag termőképességü földterület, a globális hektár; gha). Az ingázásból származó ökológiai lábnyom kérdése azért bír rendkívüli jelentőséggel, mert az ebből származó átlagos ökolábnyom nagyobb, mint a táplálkozásból származó ökológiai lábnyom, s ezt akkor sem tudnánk érdemben kompenzálni, ha táplálkozási szokásainkat drasztikusan átalakítanánk. Kiemelkedőek a részletes számításokon alapuló és módszertani szempontból élenjáró kanadai kutatások (Anielski 2010; Wilson - Anielski 2015). Anielski (2010) szerint Edmonton ökológiai lábnyomának 9,1\%-áért felelős a közlekedés és becslése szerint a közösségi közlekedés, gyaloglás és kerékpározás térnyerésével a városban az egy főre eső ökológiai lábnyom mintegy 0,5 globális hektárral csökkenthető lenne. Egy másik tanulmányában szerzőtársával megállapítja, hogy 2014-ben Saskatoon ökológiai lábnyomának 12\%-áért volt felelős a közlekedés, és a közlekedési lábnyom 2003 és 2014 között 40\%-kal nőtt a városban (Wilson - Anielski 2015). Joggal merülhet fel tehát a kérdés, hogy új közlekedési technológiák alkalmazása, az autóforgalom korlátozása, esetleg forgalomszervezési újítások mellett gazdasági oldalról milyen lehetőségek kínálkoznak a forgalom egy részének kiváltására anélkül, hogy a társadalom tagjainak térbeli mozgását korlátoznánk. Az egyik ilyen innovatív megoldást a közösségi gazdaság (sharing economy) jelentheti.

A brit PWC (2016) jelentése szerint a közösségi gazdaság öt vezető ága (szállás, közlekedés, háztartási szolgáltatások, pénzügyek, üzleti szolgáltatások) 2015-ben Európában összesen 3,6 milliárd euró bevételt generált, és további 28 milliárd euró üzleti forgalomhoz járult hozzá valamilyen formában. A sharing economy részesedése dinamikusan növekszik: ugyancsak a PWC elörejelzése szerint 2025-ig a közösségi gazdaság forgalma éves szinten 35\%-kal nő, szemben a hagyományos üzleti tevékenységek 3\%-ával. Várakozások szerint a szektorból származó bevételek összege 2025-re elérheti a 310-330 milliárd eurót.

A közösségi gazdaság terjedésével egyre inkább előtérbe kerül az a kérdés, hogy a sharing economy hogyan befolyásolja a nagyvárosi régiókban a közlekedést, a személy- és teherszállítást, illetve hogyan vehet részt a városok közlekedésének jövőbeli fejlődésében, s milyen stratégiákat kellene erre vonatkozóan megfogalmazniuk a döntéshozóknak?

Tanulmányunkban a közösségi gazdaság közlekedéssel összefüggő lehetséges hatásait vizsgáljuk a budapesti városrégióban és az alábbi három fő kérdésre keressük a választ:

1. Mit mutatnak a nemzetközi és hazai tapasztalatok a telekocsi és autómegosztó rendszerek közösségi gazdaságban játszott szerepéről és lehetőségeiről?

2. A statisztikai adatok alapján melyek a legfontosabb ingázási viszonylatok a budapesti várostérségben, és ezek hogyan járulnak hozzá az ingázásból származó ökológiai lábnyomhoz?

3. Milyen szerepet játszanak a telekocsi és autómegosztó rendszerek napjainkban a budapesti várostérség ingázásában? Milyen potenciállal, illetve lehetőségekkel bírnak az ökológiai lábnyom esetleges jövőbeni csökkentésében?

Kutatási kérdéseinkhez kapcsolódóan a tanulmány első részében áttekintjük a közösségi gazdaság, azon belül kiemelten a közlekedéshez kapcsolódó üzleti tevékenységek fejlődését és legfontosabb nemzetközi tapasztalatait, majd megvizsgáljuk az in- 


\section{Környezetvédelem}

gázási viszonylatok és az ökológiai lábnyom összefüggéseit a budapesti várostérségben, végül áttekintjük a telekocsi és autómegosztó rendszerek jövőbeni lehetőségeit a budapesti városrégióban.

\section{A KÖZÖSSÉGI GAZDASÁG (SHARING ECONOMY) FOGALMA ÉS JELLEMZÖI}

A sharing economy, vagy közösségi gazdaság lényegében egy ernyőfogalom, amely a fogyasztás online platformokon történő megosztását jelenti. Jelenleg nincs egységesen elfogadott definíció a közösségi gazdaságra, mivel nincs konszenzus arra vonatkozóan, hogy tulajdonképpen mely szervezetek és üzleti vállalkozások sorolhatók a közösségi gazdaság körébe.

Richardson (2015) szerint a sharing economy nem más, mint online platformok által támogatott, alulhasznosított, profitorientált és nonprofit források, eszközök vagy javak cseréje. Felländer et al. (2015) szerint a közösségi gazdaság a materiális és immateriális javak cseréjét jelenti globális és lokális értelemben, ami csökkenti a felhasználók tranzakciós költségeit és általában egy közvetítő harmadik fél digitális platformján keresztül zajlik. Rinne (2017) hangsúlyozza, hogy a hatékonyság, fenntarthatóság és közösségi jelleg kiemelt szerepet játszik a közösségi gazdaságban. Ezen túlmenően, a közösségi gazdaság a hagyományos, növekedésorientált gazdaság számos gyengeségével szemben is alternatívát kínál.

A közösségi gazdaság fogalma szorosan kapcsolódik az együttmüködö fogyasztás (collaborative consumption) elméletéhez, amely a javak és szolgáltatások bérlésen, kereskedelmen vagy cserén keresztüli fogyasztásával függ össze. A kollaboratív fogyasztást a közösségi gazdaság részének (részhalmazának) tekintik, s szükebb értelemben azt jelenti, amikor a termék vagy szolgáltatás megszerzése és elosztása valamilyen díj vagy ellenszolgáltatás révén valósul meg. A fent említett folyamatokban meghatározó szerepe van az online piacoknak és a social network technológiáknak, amelyek támogatják a javak és források peer-to-peer megosztását (vagyis amikor az internetes hálózat végpontjai közvetlenül kommunikálnak egymással). A közösségi gazdaság jellegzetessége, hogy mind a kínálati, mind a keresleti oldalon egyének, természetes személyek vannak, nem pedig vállalatok, vagyis a közösségi gazdaság digitális platformok által támogatott peer-topeer vagy person-to-person gazdasági tevékenység.

A közösségi gazdaság jelentősége abban rejlik, hogy a javak birtoklása helyett alapvetően a közös használatra, cserére, bérlésre helyezi a hangsúlyt, amelynek során a tulajdonos kihasználatlan vagy használaton kívüli javait, eszközeit vonja be a folyamatba és teszi elérhetővé olyanok számára, akik ezt igénylik. Amennyiben a szolgáltatás keretében materiális jószágot, terméket, fizikai vagyontárgyat vehetünk igénybe, termékszolgáltatásról beszélhetünk (product-service economy). Ettől megkülönböztethetjük a gig economy fogalmát (Freidmann 2014), amikor hosszabb-rövidebb munkajellegü szolgáltatást, tevékenységet veszünk igénybe (pl. személy- vagy teherfuvarozás egyik helyről a másikra). A gig economy tehát alapvetően a munkaerő részvételére és a gigeken (hakni, alkalmi munka) keresztüli bevételnövelésre épül, olyan projekteket és feladatokat takar, amelyek végrehajtására munkaerőt bérelnek vagy kölcsönöznek. Hasonló elven működik a szabadúszók gazdasága, más néven a freelance economy is (Rinne 2017).

A közösségi gazdaság Schor (2014) megállapítása szerint az 1990-es években indult fejlödésnek, amikor megjelentek az első olyan weboldalak (pl. eBay), amelyek többek között használt termékek újrahasznosításával, eladásával foglalkoztak. Kétségtelen ugyanakkor, hogy a szektor rohamos fejlödése és térhódítása inkább az utóbbi egy évtizedre tehető. A Boston Consulting Group felmérései szerint a 2007 és 2016 közötti évtizedben megtízszereződött a közösségi gazdaságban tevékenykedő start-up vállalkozások száma, miközben 2010-2017 között több mint 23 milliárd dollár vállalkozói tőke vándorolt a szektorba (Wallenstein-Shelat 2017). 
A Deloitte (2016) adatai szerint a közösségi gazdaságon belül a bevételek legnagyobb hányada a szállásszolgáltatásokból származik, de sok országban a közlekedési és szállítási szolgáltatások már túlszárnyalják ezt a szektort. Az elmúlt évtizedben a fejlődési folyamat jellemzője volt, hogy egyre több területen jelentek meg a közösségi gazdaság start-up cégei: a B2P, illetve B2C vállalkozások egyértelműen túlléptek az utazás- és szállásmegosztó szolgáltatásokon és olyan új területeken indult hódító útjára a közösségi gazdaság, mint a munkahely-, tárolóhely-, fuvarozás- és logisztikai megosztások.

A sharing economy azokon a területeken lehet sikeres, ahol a konvencionális üzleti modell a jelentkező keresletet és szükségleteket nem képes megfelelö módon ellátni. A kereslet kielégítésére létrehozott internetes platformok összehozzák a felhasználókat, s ezeken a platformokon keresztül kicserélhetik egymás között kapacitásaikat vagy forrásaikat. A sharing economy fejlődése tehát szorosan öszszefonódik a digitális hálózatok fejlődésével, bővülésével.

Mivel a közösségi gazdaságban való részvétel bizonyos szintü internetes készségeket igényel, ezért föleg a fiatalabb, képzettebb és magasabb jövedelmű rétegek körében népszerü (Santoso - Nelloh 2017). Az ilyen szolgáltatásokat kínálók legmagasabb arányban a 25-34 éves korosztályhoz köthetők, míg a szolgáltatásokat igénybe vevők aránya az ennél valamivel fiatalabb, 18-24 éves korcsoportban a legmagasabb. A közösségi gazdaság és az iskolai végzettség közötti öszszefüggésről megállapíthatjuk, hogy minél magasabb valakinek a végzettsége, várhatóan annál intenzívebb a részvétele ebben az üzleti formában, különösen a keresleti oldalon. A közösségi gazdaság jelenlegi formájában tehát erősen elitista jellegü. Ezt egyértelmüen alátámasztják a jövedelmi mutatók is: a magasabb jövedelem aktívabb részvétellel jár. A kereslet-kínálat oldalát külön is megvizsgálva elmondható, hogy a keresleti oldalon a magasabb jövedelműek dominálnak felhasználóként, míg az alacsonyabb jövedelműek inkább a kínálati oldalon tünnek fel. Emellett általános, hogy a férfi felhasználók aktívabban vesznek részt a közösségi gazdaságban. Társadalmi hatásait tekintve megállapítható, hogy a sharing economy nem alakít ki hoszszan tartó társadalmi kapcsolatokat és kötelékeket, sokkal inkább értelmezhető alkalomszerüen létrejött gazdasági tranzakciók sorozataként.

Botsman és Rogers (2010) tették az első átfogó kísérletet arra, hogy a közösségi gazdasághoz tartozó vállalkozásokat osztályozzák. A vállalkozásokat három alapvető csoportba osztották: a) termékszolgáltatási rendszerek (amikor egy terméket, mint szolgáltatást nyújtják, pl. Zipcar); b) újraelosztási hálózatok (amikor a termék életciklusát bővítik új ügyfelek bevonásával, pl. eBay); c) kollaboratív életstílus (immateriális javak szolgáltatása, pl. Uber).

Petrini et al. (2017) a sharing economy három archetípusát különbözteti meg: a) új üzleti modellek, amelyek az új piaci szereplők technológiai platformjain alapulnak, a tevékenység a vállalat fö üzleti profilját jelenti, amelyben a szolgáltatásért költségeket számolnak fel; b) tradicionális piaci modellek újradizájnolt formái, amelyek a fogyasztók számára idő- és pénztakarékos megoldásokat nyújtanak; c) idealista megosztási modell, amely fenntartható alternatív fogyasztási modelleket foglal magába.

Mivel a közösségi gazdasággal összefüggő tevékenységek legtöbbször a személyes és kereskedelmi tevékenységek határmezsgyéjén mozognak és sok esetben sértik a régóta meglévő, tradicionális gazdasági normákat, ezért a hagyományos jogi keretek általában nem kedveznek a közösségi gazdaságnak. Ha egy ország vagy város aktívabban részt szeretne venni ebben, újra kellene gondolnia a jogi és szabályozási kereteit. Mivel a sharing economy általában innovatív és kreatív üzleti modelleket és tevékenységeket foglal magába, a túlszabályozottság semmiképpen sem járul hozzá a szektor fejlődéséhez. Tény ugyanakkor, hogy az egyre növekvő számú résztvevő miatt bizonyos fokú szabályozásra szükség van. 


\section{Környezetvédelem}

\section{A RIDE-SHARING, CAR- SHARING ÉS CAR-POOLING SZEREPE A KÖZÖSSÉGI GAZDASÁGBAN}

Tanulmányunk a közösségi gazdaság közlekedéssel összefüggő kérdéseit vizsgálja, így külön kell szólnunk a ride-sharing, carsharing és car-pooling tevékenységekről. A ride-sharing (útmegosztás, utazásmegosztás) olyan szolgáltatás, amikor a résztvevő egy online vagy mobilapplikáción keresztül megrendel, kibérel egy utazást és fizet érte. Ridesharing alkalmával az utas egyedül utazik, ilyen szempontból klasszikus értelemben vett „útmegosztás” nem jön létre. Ebben az esetben a folyamat inkább egyfajta taxi szolgáltatáshoz hasonlít, amelyben a vezető megosztja a jármüvét az utassal (pl. Uber), és további utasok csatlakozása általában nem lehetséges. Környezeti szempontból nincs pozitívuma, mert sem a zsúfoltságot, sem pedig az ökológiai lábnyomot nem csökkenti, viszont gazdasági haszonnal járhat a résztvevők számára, bár az adóelkerülés miatt jelentős társadalmi konfliktusok forrása is lehet. Az Uberhez hasonló szolgáltatást kínál egy magyar startup, a Hoopps (www.hoopps.com ), amely készpénzmentes, jobban szabályozott és extra szolgáltatásokat is nyújt az Uberhez képest. A ride-sharing körébe sorolható a szállítmányozási szektorban müködő megosztás is, amikor helyet biztosítanak a szállítandó rakomány számára, vagy vállalja a fuvarozó a rakomány elszállítását egy általa vállalt útvonalon (pl. B2B). Sok szerző vitatja, hogy a ride-sharing vagy ride-sourcing a közösségi gazdasághoz tartozik.

A ride-sharing története közel egyidős az automobilok történetével. Néhány évvel az autógyártás megindulása után, az I. világháború előestéjén az Egyesült Államok gazdasága recesszióba került, ami hatással volt a városokban egyre inkább tömegessé váló autóközlekedésre is. Néhány Los Angeles-i vállalkozó elkezdett utasokat szállítani a kocsijában az akkoriban szokásos ötcentes (a köznyelvben jitney) fuvardíjért. Az ötlet rendkívül gyorsan elterjedt, s 1914 decemberére már 1500 hivatalos engedéllyel rendelkező autós szállította az utasokat és a munkásokat a városban. Az ún. Jitney Craze szűk egy év alatt meghódította az Egyesült Államok nagyvárosait. A ride-sharing (car-sharing és car-pooling) második - modernnek nevezhető - időszaka a II. világháborúra tehető, amikor 1941 és 1945 között az amerikai kormány az olajipari társaságok közremüködésével, elsősorban üzemanyag-takarékossági okokból, népszerüsítette az autómegosztó és telekocsi klubokat. A ride-sharing fejlődésének harmadik jelentős korszaka az 1970-es évtized olajválságaira tehető, amikor a dráguló üzemanyagárakra autómegosztással válaszoltak az utazók. A statisztikai adatok tanúsága szerint az Egyesült Államokban 1970 és 1980 között a népesség egyötöde utazásmegosztással járt munkába (MIT 2009). Ekkor jelentek meg a nagyvárosi közlekedésben a $\mathrm{HOV}$ (highoccupancy vehicle) külön sávok és terjedtek el a park-and-ride parkoló rendszerek. A ridesharing negyedik időszaka 1980 és 1997 közé tehető: az üzemanyagárak csökkenésével az utazásmegosztás jelentősége alapvetően csökkent ebben a bő másfél évtizedben, viszont ekkor jelentek meg a korai, szervezett utazásmegosztó szolgáltatások, amelyek még telefonos közvetítéssel müködtek. 1999 és 2004 között terjedtek el az internetes technológiákat alkalmazó utazásmegosztó szolgáltatások, amit a fejlődési folyamat ötödik állomásaként értelmezhetünk. Az utóbbi két időszakban az utazásközvetítés egyik fö célkitüzése városfejlesztési szempontból - már a gépkocsiforgalom csökkentése és a levegőminőség javítása volt. Az utolsó, immár hatodik szakasz 2004-től napjainkig tart, fö jellemzője az IKT technológiák által támogatott valós idejü szolgáltatások elterjedése, amely mögött már egyértelmüen kitapinthatók a klímaváltozással kapcsolatos aggodalmak, s ezzel összefüggésben a szén-dioxid-kibocsátás és az ökológiai lábnyom csökkentésének koncepciója. A szolgáltatások kiemelt célcsoportját jelentik a fiatalok, s a folyamatban fontos szerepet játszanak a közösségi hálózatok és az IKT platformok.

A car-sharing a közlekedési eszköz kibérlésen alapuló megosztását jelenti egy utazásra. Ez történhet úgy is, hogy egy jelentősebb cég 
adja bérbe a használt autókat, vagy egy természetes személy adja bérbe a saját jármüvét ( $\mathrm{pl}$. GreenGo, Zipcar). Car-sharing esetén tehát az ügyfél bérli a járművet ahelyett, hogy megvenné. A legfontosabb car-sharing rendszerek a következők:

a. A "peer-to-peer car sharing" (P2P) esetén az autó magánszemély tulajdonában van, aki P2P platformon keresztül kínálja megosztásra. Magyarországon is müködő P2P a BeeRides, a parkoló a Liszt Ferenc repülőtér közelében található.

b. A „stationary car sharing” (S) vagy klasszikus autómegosztó szolgáltatás lényege hogy a kerékpármegosztó rendszerekhez hasonlóan a kocsit a kijelölt állomásokon lehet átvenni és leadni. Megkülönböztethetjük a kétutas (twoway) és az egyutas (one-way) modellt: az előbbinél az autót ugyanahhoz az állomáshoz kell visszavinni ahonnan elhozták, az egyutas modellnél eltérhet a két pont egymástól (Ferrero et al 2018). Magyarországon is müködő S szolgáltatás az Avalon Car(e) Sharing.

c. A "free-floating car sharing" (FF) autómegosztó rendszerben a felhasználók a közlekedés szabályainak betartása mellett bárhol otthagyhatják az autót, ha már nincs rá szükségük, illetve beülhetnek a flottához tartozó első szabad kocsiba, amely a közelben parkol. Magyarországon müködő e-autó megosztó a Greengo és a MolLimo.

A modern értelemben vett car-sharing az 1980-as évek második felében Svájcból és Németországból indult hódító útjára, tömeges elterjedése az 1990-es évtizedre tehető. 2014ben a regisztrált car-sharing felhasználók száma 4,8 millió fö volt, ami napjainkban exponenciálisan növekszik, és 2020-ra 20 millió felhasználóra számítanak a car-sharing operátorok (Frost \& Sullivan 2010). A közösségi gazdaságban a klasszikus üzletvitelü, hagyományos vállalatok (pl. autógyártó cégek) csak úgy tudnak sikeresen részt venni és részesedésüket növelni, ha a gyártás mellett járműkölcsönzéssel vagy szállítmányozással bővítik profiljukat. A car-sharing is jelentősen hozzájárulhat a gépjárműforgalom csök- kenéséhez, a car-sharingben ugyanis nagy arányban vesznek részt olyanok, akik nem akarnak vagy nem tudnak saját gépkocsit tulajdonosként fenntartani. Söt a car-sharinget használó háztartások gyakran eladják feleslegessé váló második vagy harmadik kocsijukat, esetleg elhalaszthatják további autó(k) vásárlását.

A car-sharing és car-pooling rendszereket érdemes egymástól elválasztva kezelni. Míg az autómegosztás egy diverzifikált piaci modell, a telekocsi elsősorban közösségi megoldás (az utasoktól elvárás, hogy szükség esetén megoszszák az autót más utasokkal, a gépjármü pedig általában a vezető tulajdonában van) (1. ábra).

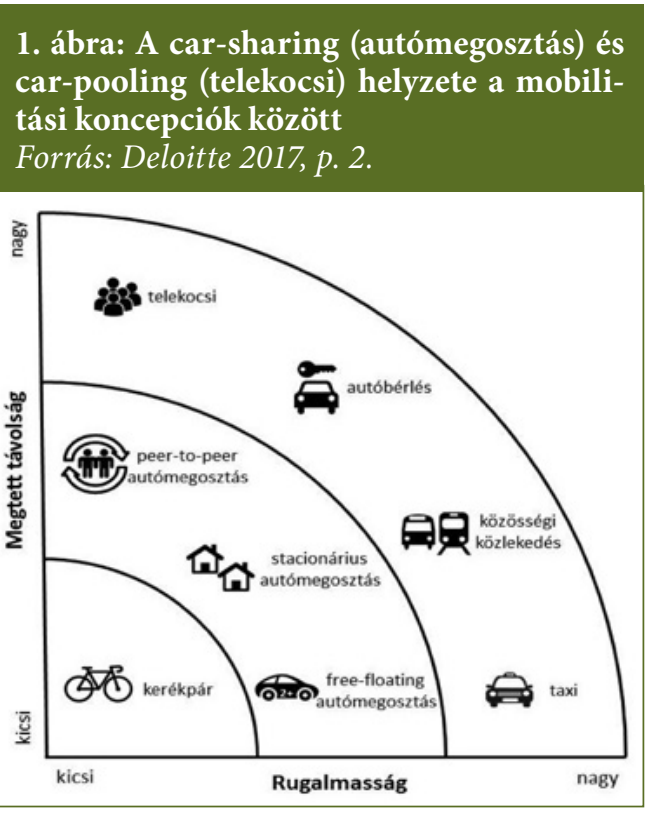

A car-pooling olyan útmegosztás, amely a ride- és car-sharinggel ellentétben nem egy megrendelésen (kibérlésen) alapuló tranzakció, hanem több ember osztja meg a közlekedési eszközt egy utazás során. Ez történhet rendszeresen vagy egyszeri utazás alkalmával is. A folyamatban lehetséges és sokszor jellemző a költségek megosztása az utazók között, de alapvetően nem egy kereskedelmi szerződésről van szó. Magyarországon jelenleg müködő autómegosztó az Oszkár és a BlaBlaCar. 


\section{Környezetvédelem}

A car-pooling egy magántulajdonban lévő gépjármü használatával lehetővé teszi egy utazás és a vele járó költségek megosztását két vagy több, nem egy háztartáshoz tartozó személy részére. Ez általában úgy jön létre, hogy az utasok hozzájárulnak a sofőr (autótulajdonos) üzemanyagköltségeihez. Car-pooling már évtizedek óta létezik, de az internet és a közösségi háló a szolgáltatás robbanásszerü elterjedését hozta magával. A résztvevők száma alapvetően meghatározza a car-pooling sikerességét, nagyszámú résztvevő esetén pedig komoly hatásai lehetnek egy nagyváros közlekedésére és gazdaságára is. ConnerSimmons (2016) kimutatta, hogy a carpooling akár $75 \%$-kal is képes csökkenteni a taxiforgalmat egy nagyvárosban, s különösen a sürün lakott nagyvárosi régiókban lehet sikeres, ahol a potenciális használók száma magas. A car-pooling elsősorban a kékgalléros munkások körében népszerü és különösen akkor, ha közlekedési (ingázási) vagy anyagi lehetőségeik korlátozottak. A car-pooling használatának legfontosabb motiváló tényezői a kedvezőbb költségek, az olcsóbb utazás és a költségtakarékosság. Emellett környezeti hatásokat is említhetünk, hiszen a szolgáltatással nő az autók kihasználtsága, ami végső soron az autók számának csökkenéséhez vezet (Belk 2014), a környezet javuló állapota (jobb levegőminőség, alacsonyabb zajterhelés) pedig gazdaságilag is kimutatható hasznot jelent a társadalom számára. Utóbbi erőforrás-felhasználások megfigyelésében, mérésében, feljegyzésében és az információ szolgáltatási kötelezettség szabályozásában a környezeti nemzeti számvitel is fontos szerepet játszik, amely a természeti erőforrásokra, a környezeti költségekre és az externáliákra fókuszál.

A jövőben a vezető nélküli járművek megjelenése is várható a nagyvárosi közlekedésben (az első próbálkozásokon már túl vagyunk). Ezek hatása a helyi közlekedésre kétséges, a szakértők két, egymással szöges ellentétben álló álláspontra helyezkednek. Egyik csoportjuk szerint a sharing economy és a vezető nélküli járművek alkalmazása az autóforgalmat drasztikusan csökkenteni fogja, mivel az integrált rendszernek köszönhetően mindenki időben eljut majd az általa kívánt helyre. A felszabaduló területeket pedig egyéb, új funkciókra fordíthatják. A szakértők másik csoportja szerint a jövőbeli folyamatok jelentős forgalomnövekedéssel járnak, mivel az utazás lényegesen egyszerübbé és olcsóbbá válik, aminek köszönhetően egyre szélesebb tömegek (szegényebb és hátrányos helyzetü csoportok, mozgáskorlátozottak stb.) kapcsolódnak be a közlekedésbe.

\section{AZ AUTÓMEGOSZTÓ ÉS TELEKOCSI RENDSZEREK HASZ- NÁLATÁNAK NEMZETKÖZI TAPASZTALATAI}

Ferrero et al. (2018) munkájukban 137 publikációt tekintettek át, amelyek az autómegosztás szerepével és hatásaival foglalkoznak. Megállapították, hogy a gépjármümegosztás egyre népszerübbé válik a világ minden táján, $s$ véleményük szerint a jelenség hátterében a környezeti kérdésekre irányuló fokozódó figyelem mellett az információs és kommunikációs technológiák (IKT) fejlődése áll. Ez teszi lehetővé, hogy a szolgáltatások mobileszközökön is elérhetők legyenek széles felhasználói kör számára.

Braun (2017) kutatásai szerint az autóval nem rendelkező háztartásoknak két alapvető típusát különböztethetjük meg: a saját döntésük alapján autómentes (carfree) és a kényszerből autó nélkül élő (carless) háztartásokat. Az első csoportba azok a háztartások tartoznak, amelyek például környezetvédelmi okok miatt tudatosan döntenek úgy, hogy nem vásárolnak autót, s inkább a közösségi közlekedést használják. A második csoportba azok tartoznak, akik anyagi vagy egészségügyi okokból nem engedhetik meg maguknak az autóvásárlást, vagy nem szereztek jogosítványt. A kutatás eredményei szerint az autómegosztó szolgáltatásokat legnagyobb arányban a környezetvédelmi okokból autóvásárlást elutasító, magas jövedelmű „carfree” háztartások tagjai vették igénybe. Ha az autómegosztásnak a közlekedésből származó üvegházhatású gázok (ÜHG) kibocsátásra gyakorolt hatását kívánjuk vizsgálni, akkor pozitív és negatív hatásokkal is számolnunk kell. Csökkenti az ÜHG- 


\section{2. ábra: Az autómegosztás piacának bőviilése Európában Forrás: Deloitte 2017, p. 4.}

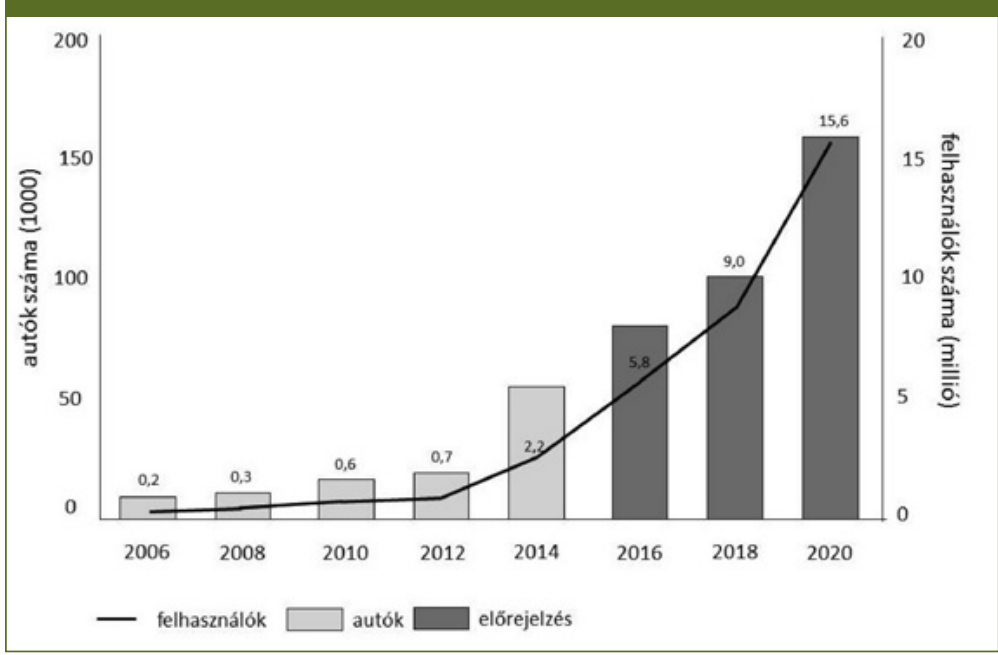

(Schmöller et al.2015). A négy vezető szolgáltató - a Car2Go, a DriveNow, a Flinkster és a Cambio - 2017ben nagyjából 12 ezer autót üzemeltetett, valamennyi szolgáltatót együttvéve pedig 15400 autómegosztós kocsi futott a német utakon. Ez a szám 2020-ig évente 1119\% közötti mértékben emelkedhet, így a szolgáltatás tömegessé válhat. A berlini városvezetés szerint ezért szükség van arra, hogy szabályozzák a piac müködé-

kibocsátást, ha a kisebb fogyasztású, hatékonyabb autókat használják a közlekedők, illetve a megosztási lehetőség miatt kevesebb autót használnak. A növekedés irányába hathat ugyanakkor, ha a közösségi közlekedés helyett választják a közlekedők az autómegosztást.

Egy svájci kutatás eredményei alapján az egyéni utazási magatartás nagymértékben megváltozik az elérhető mobilitási eszközök, mint például az autómegosztás portfóliójának változásával (Becker et al. 2017). A kutatók szerint a különböző mobilitási eszközök választéka egymástól is függ, valamint az egyéni attitüdök is befolyásolják. A 2005. és 2010. évi svájci mikro-cenzusok közlekedési adatai szerint az autómegosztás a közösségi közlekedés-orientált életmód kiegészítéseként jelenik meg, de az autótulajdonosok is használják. A Deloitte (2017) Európára kiterjedő piaci elemzése és előrejelzése egyértelműen jelzi az autómegosztás napjainkban tapasztalható, $s$ várható dinamikus bővülését (2. ábra).

Az autóipari nagyhatalomnak számító Németországban is egyre jelentősebb szerepet töltenek be a városi közlekedésben a free-floating autómegosztók. A szolgáltatás elterjedése erősen koncentrált, különösen a milliós nagyvárosokban (Berlin és München) jellemző sét. Az autómegosztók szolgáltatási területeit vizsgálva jól látható, hogy ezek a piacvezető rendszerek egyelöre nem jelentek meg KeletKözép-Európában, de Bécsben már igen, így a német példa alapján fel kell készülni az ezzel járó versenyhelyzetre (1. táblázat).

Perboli et al. (2017) tanulmányukban azt vizsgálták, hogy a Torinóban müködő autómegosztó szolgáltatások igénybevétele vagy a saját autó fenntartása éri-e meg jobban. Eredményeik szerint az ingázóknak évi 5000 km-ig nem érdemes saját autót fenntartani, viszont éves szinten 10 ezer $\mathrm{km}$ felett már a saját autó fenntartása a kedvezőbb megoldás. Az autómegosztók közül az elektromos autókat kínáló klasszikus (S) autómegosztó, a Blue Torino szolgáltatásait találták a legkedvezőbbnek. A Blue Torinot működtető francia Bolloré Group Autolib rendszere Párizsban is kiterjedt autómegosztó hálózatot üzemeltet, amely a várostérségben is elérhető.

\section{AZ INGÁZÁS ÉS AZ ÖKOLÓGIAI LÁBNYOM KAPCSOLATA A BUDAPESTI VÁROSRÉGIÓBAN}

Jelen tanulmány szorosan kapcsolódik a Területi Statisztika folyóirat 2017/4. számában megjelent írásunkhoz, amelyben a budapesti 


\begin{tabular}{|c|c|c|}
\hline Szolgáltatók & Országok & Városok \\
\hline \multirow[t]{8}{*}{$\begin{array}{l}\text { Car2Go } \\
\text { https://www.car2go.com }\end{array}$} & USA & $\begin{array}{l}\text { Austin, Columbus, Denver, New York City, } \\
\text { Portland, Seattle, Washington }\end{array}$ \\
\hline & Ausztria & Bécs \\
\hline & Kanada & Calgary, Montreal, Toronto, Vancouver \\
\hline & Kína & Chongquing \\
\hline & Németország & $\begin{array}{l}\text { Berlin, Frankfurt, Hamburg, München, } \\
\text { Rheinland, Stuttgart }\end{array}$ \\
\hline & Olaszország & Florence, Milánó, Róma, Turin \\
\hline & Hollandia & Amszterdam \\
\hline & Spanyolország & Marid \\
\hline \multirow{6}{*}{$\begin{array}{l}\text { DriveNow } \\
\text { https://www.drive-now.com }\end{array}$} & Ausztria & Bécs \\
\hline & Németország & Berlin, Köln, Düsseldorf, Hamburg, München \\
\hline & Nagy-Britannia & London \\
\hline & Dánia & Koppenhága \\
\hline & Svédország & Stockholm \\
\hline & Belgium & Brüsszel \\
\hline $\begin{array}{l}\text { Flinkster } \\
\text { https://www.flinkster.de }\end{array}$ & $\begin{array}{l}\text { Németország, Hollandia, Olasz- } \\
\text { ország, Svájc }\end{array}$ & 2500 állomás, 400 város, 4000 jármü \\
\hline $\begin{array}{l}\text { Cambio } \\
\text { https://www.cambio-carsharing.de }\end{array}$ & Németország & $\begin{array}{l}\text { Aachen, Berlin, Bielefeld, Bonn, Bremen, } \\
\text { Bemenhaven, Düren Eschweiler, Flensburg, } \\
\text { Hamburg, Herzogenrath, Hürth, Jülich, Köln, } \\
\text { Lüneburg, Oldenburg, Saarbrücken, Uelzen } \\
\text { Winsen, Wuppertal, Würselen }\end{array}$ \\
\hline
\end{tabular}

Forrás: Szolgáltatók honlapjai alapján saját adatgyűjtés

városrégió ingázási folyamatait, valamint a hozzá kapcsolódó ökológiai lábnyom időbeli változásait foglaltuk össze (Kovács et al. 2017). Korábbi írásunk jelen tanulmány szempontjából legfontosabb megállapításait az alábbiak szerint foglalhatjuk össze: az ezredforduló után jelentősen nőtt az ingázás volumene a budapesti városrégióban, ami értelemszerüen jelentősen növelte az ingázásból eredő ökológiai lábnyomot. Az egy ingázóra jutó ökológiai lábnyom 2011-ben 0,53 globális hektár volt, ami azt jelenti, hogy az ökológiai lábnyom közel ötöde (19\%) származott az ingázásból. Ökológiai szempontból a legnagyobb problémát az jelenti, hogy az ezredforduló utáni évtizedben közel 90 ezer fővel nőtt a fosszilis üzemanyagot használó közlekedési eszközökkel - elsősorban személygépkocsival - utazók száma (lásd még Kiss - Szalkai 2018). Kimutatható az is, hogy az ingázók egyre kevésbé kombinálják a különböző közlekedési módokat, és egyre gyakrabban nyúlnak az egyedi igényeket jobban kielégítő személygépkocsihoz. Ez többek között arra vezethető vissza, hogy a városrégió policentrikus fejlődése miatt új cirkulációs mobilitási formák (pl. városok közötti keresztirányú ingázás) jelentek meg (Szabó, T. et al. 2014).

Az ingázásból származó ökológiai lábnyomot jelentősen csökkenteni lehetne a közlekedés racionalizálásával. Nem véletlen, hogy az Európai Unió országaiban a közlekedési hálózatoknak megfelelően alakítják ki a városhálózatfejlesztési koncepciókat. Ebben kiemelt szerep jut a közösségi közlekedés fejlesztésének, ami minden államnak elemi érdeke. Ugyanakkor a közösségi közlekedés jelentőségét az ingázásban fizikai tényezők és pszichológiai okok is 


\section{2. táblázat: A legtöbb ingázót érintő viszonylatok toplistája}

a budapesti városrégióban 2011-ben

\begin{tabular}{|l|c|c|c|c|}
\hline & \multicolumn{4}{|c|}{ legtöbb ingázót érintő viszonylatok } \\
\hline & $\begin{array}{c}\text { foglalkoztatot- } \\
\text { tak száma (fö) }\end{array}$ & $\begin{array}{c}\text { EF } \\
\text { (gha) }\end{array}$ & $\begin{array}{c}\text { foglalkoztatot- } \\
\text { tak \% }\end{array}$ & $\begin{array}{c}\text { EF } \\
\%\end{array}$ \\
\hline top 10 & 61362 & 6517,35 & 16 & 8 \\
\hline top 20 & 91876 & 11163 & 24 & 14 \\
\hline top 100 & 196294 & 30641,49 & 52 & 38 \\
\hline $\begin{array}{l}\text { várostérséget } \\
\text { érintő viszonyla- } \\
\text { tok a top 100-ból }\end{array}$ & 185110 & 25402,77 & 94 & 83 \\
\hline
\end{tabular}

Forrás: a 2011. évi népszámlálás alapján saját számítás

3. táblázat: Az ökológiai lábnyomhoz legnagyobb mértékben
hozzájáruló ingázási viszonylatok toplistája 2011-ben
\begin{tabular}{|l|c|c|c|c|}
\hline & \multicolumn{4}{|c|}{ legnagyobb ökológiai lábnyomú (EF) viszonylatok } \\
\hline & $\begin{array}{c}\text { foglalkoztatot- } \\
\text { tak száma (fö) }\end{array}$ & $\begin{array}{c}\text { EF } \\
\text { (gha) }\end{array}$ & $\begin{array}{c}\text { foglalkoztatot- } \\
\text { tak\% }\end{array}$ & $\begin{array}{c}\text { EF } \\
\%\end{array}$ \\
\hline top 10 & 36578 & 8020,81 & 10 & 10 \\
\hline top 20 & 67200 & 13043,88 & 18 & 16 \\
\hline top 100 & 183516 & 34401,76 & 48 & 43 \\
\hline $\begin{array}{l}\text { várostérséget } \\
\text { érintő viszonyla- } \\
\text { tok a top 100-ból }\end{array}$ & 164500 & 23833,37 & 90 & 69 \\
\hline
\end{tabular}

Forrás: a 2011. évi népszámlálás alapján saját számítás

hátrányosan érintik (hiányzó vagy korlátozott szolgáltatások; az emberek egy része minden erőfeszítés ellenére sem fogja igénybe venni a közösségi közlekedést).

Az ökológiai lábnyom csökkentését alapvetően a fosszilis üzemanyagot használó gépjárművek - elsősorban személygépkocsik - számának csökkentésével vagy a kötött pályás közlekedési módok fejlesztésével érhetjük el. Ehhez a problematikához kapcsolódik tanulmányunk egyik fö kérdése, hogy vajon a közösségi gazdasághoz sorolható car-pooling és car-sharing segítségével milyen lehetőségek kínálkoznak a budapesti városrégióra nehezedő környezeti nyomás csökkentésére? A kérdés megválaszolásához elsőként vizsgálatot végeztünk arra vonatkozóan, hogy a budapesti városrégión belül mely ingázási viszonylatok járulnak hozzá a legnagyobb mértékben az ökológiai lábnyomhoz (a vizsgálat módszertani hátterét lásd Kovács et al. 2017).

A 2011. évi népszámlálási adatok alapján a budapesti városrégióban 14740 db ingázási viszonylatot regisztráltunk, amelyekből $13911 \mathrm{db}$ volt az 50 főnél kevesebb ingázót érintő viszonylatok száma. Az ingázás erős koncentráltságot mutat: az ingázók száma alapján felállított sorrendet szemügyre véve azt mondhatjuk, hogy a várostérség 14740 db viszonylatából a legtöbb ingázót érintő első 100 db viszonylat az összes ingázó több mint 50\%át tömöríti, és ezen viszonylatok felelösek az ingázásból származó ökológiai lábnyom 38\%-áért gázók 94\%-a a lehatárolt városrégión belül ingázik. Eredményeink alapján arra következtethetünk, hogy a viszonylatok kevesebb mint egy százalékában ingázik a foglalkoztatottak több mint fele. Hasonló arányszámokat és koncentráltságot mutathatunk ki, ha nem az ingázók száma, hanem az ökológiai lábnyom alapján állítjuk fel a viszonylatok sorrendjét (3. táblázat).

Tovább finomíthatjuk eredményeinket és pontosabb képet kaphatunk a városrégión belüli viszonyokról, ha vizsgálatainkat leszűkítjük az ingázók száma, illetve az ökolábnyom nagysága alapján felállított sorrendek top 10 viszonylatára. A legtöbb ingázót érintő top 10 viszonylat az ingázók 16\%-át tömörítette 2011-ben, és 


\begin{tabular}{|c|c|c|c|c|c|c|c|}
\hline lakóhely & munkahely & $\begin{array}{l}\text { Foglalkoz- } \\
\text { tatott }\end{array}$ & $\begin{array}{c}\text { Egy napra } \\
(\mathbf{k m})\end{array}$ & $\begin{array}{l}255 \text { munka- } \\
\text { napra }(\mathrm{km})\end{array}$ & $\mathrm{CO}_{2}(\mathrm{t})$ & $\begin{array}{c}\text { EF } \\
\text { (gha) }\end{array}$ & $\begin{array}{c}\text { EF } \\
\text { gha/fö }\end{array}$ \\
\hline Érd & Budapest & 10761 & 213145,5 & 54352102 & 5163,45 & 1290,86 & 0,12 \\
\hline Dunakeszi & Budapest & 9687 & 183045,8 & 46676667 & 4434,28 & 1108,57 & 0,11 \\
\hline Budapest & Budaörs & 7847 & 69616,07 & 17752097 & 1686,45 & 421,61 & 0,05 \\
\hline $\begin{array}{l}\text { Szigetszent- } \\
\text { miklós }\end{array}$ & Budapest & 6807 & 136924,2 & 34915677 & 3316,99 & 829,25 & 0,12 \\
\hline Budaörs & Budapest & 5392 & 47836,09 & 12198204 & 1158,83 & 289,71 & 0,05 \\
\hline Gyál & Budapest & 5006 & 96422,6 & 24587763 & 2335,84 & 583,96 & 0,12 \\
\hline Szentendre & Budapest & 4235 & 94506,74 & 24099218 & 2289,43 & 572,36 & 0,14 \\
\hline Vecsés & Budapest & 4129 & 88098,66 & 22465158 & 2134,19 & 533,55 & 0,13 \\
\hline Fót & Budapest & 3823 & 81388,08 & 20753961 & 1971,63 & 492,91 & 0,13 \\
\hline Dunaharaszti & Budapest & 3675 & 65152,95 & 16614002 & 1578,33 & 394,58 & 0,11 \\
\hline \multicolumn{2}{|l|}{ top 10 összesen } & 61362 & 1076137 & 274414849 & 26069,41 & 6517,35 & \\
\hline \multicolumn{2}{|l|}{ összesen } & 380357 & 13253901 & $3,38 \mathrm{E}+09$ & 321075,8 & 80268,94 & 0,21 \\
\hline \multicolumn{2}{|l|}{$\%$} & $16 \%$ & $8 \%$ & $8 \%$ & $8 \%$ & $8 \%$ & \\
\hline
\end{tabular}

\section{5. táblázat: Az ökológiai lábnyomhoz legnagyobb mértékben hozzájáruló ingázási viszonylatok 2011-ben}

\begin{tabular}{|c|c|c|c|c|c|c|c|}
\hline lakóhely & munkahely & $\begin{array}{l}\text { Foglalkoz- } \\
\text { tatott }\end{array}$ & $\begin{array}{c}\text { Egy napra } \\
(\mathbf{k m})\end{array}$ & $\begin{array}{l}255 \text { munka- } \\
\text { napra }(\mathbf{k m})\end{array}$ & $\mathrm{CO}_{2}(\mathrm{t})$ & $\begin{array}{c}\text { EF } \\
\text { (gha) }\end{array}$ & $\begin{array}{c}\text { EF } \\
\text { gha/fö }\end{array}$ \\
\hline Érd & Budapest & 10761 & 213145,50 & 54352101,55 & 5163,45 & 1290,86 & 0,12 \\
\hline Dunakeszi & Budapest & 9687 & 183045,75 & 46676667,04 & 4434,28 & 1108,57 & 0,11 \\
\hline $\begin{array}{l}\text { Sziget- } \\
\text { szentmiklós }\end{array}$ & Budapest & 6807 & 136924,22 & 34915677,26 & 3316,99 & 829,25 & 0,12 \\
\hline Miskolc & Budapest & 759 & 131306,03 & 33483038,81 & 3180,89 & 795,22 & 1,05 \\
\hline Debrecen & Budapest & 580 & 127444,89 & 32498448,01 & 3087,35 & 771,84 & 1,33 \\
\hline $\begin{array}{l}\text { Székes-fe- } \\
\text { hérvár }\end{array}$ & Budapest & 1893 & 115783,00 & 29524664,67 & 2804,84 & 701,21 & 0,37 \\
\hline Cegléd & Budapest & 1586 & 109647,85 & 27960202,05 & 2656,22 & 664,05 & 0,42 \\
\hline Szolnok & Budapest & 1080 & 105075,53 & 26794259,49 & 2545,45 & 636,36 & 0,59 \\
\hline Szeged & Budapest & 606 & 101997,22 & 26009291,25 & 2470,88 & 617,72 & 1,02 \\
\hline Vác & Budapest & 2819 & 100015,87 & 25504047,31 & 2422,88 & 605,72 & 0,21 \\
\hline \multicolumn{2}{|l|}{ top 10} & 36578 & 1324385,87 & 337718397,45 & 32083,25 & 8020,81 & \\
\hline \multicolumn{2}{|l|}{ összesen } & 380357 & 13253901,10 & 3379744779,31 & 321075,75 & 80268,94 & 0,21 \\
\hline \multicolumn{2}{|l|}{$\%$} & $9,6 \%$ & $10,0 \%$ & $10,0 \%$ & $10,0 \%$ & $10,0 \%$ & \\
\hline \multicolumn{2}{|c|}{$\begin{array}{l}\text { Érd+Dunakeszi+ } \\
\text { Szigetszentmiklós }\end{array}$} & 27255 & 533115,47 & 135944445,85 & 12914,72 & 3228,68 & \\
\hline \multicolumn{2}{|c|}{$\begin{array}{l}\text { Érd+Dunakeszi+Szigetszent- } \\
\text { miklós az összes arányában }\end{array}$} & $7,2 \%$ & $4,0 \%$ & $4,0 \%$ & $4,0 \%$ & $4,0 \%$ & \\
\hline
\end{tabular}




\begin{tabular}{|c|c|c|c|c|c|c|}
\hline lakóhely & munkahely & $\begin{array}{l}\text { Foglalkoz- } \\
\text { tatott }\end{array}$ & Egy napra $(\mathbf{k m})$ & $\begin{array}{l}255 \text { munka- } \\
\text { napra }(\mathrm{km})\end{array}$ & $\mathrm{CO}_{2}(\mathrm{t})$ & $\begin{array}{c}\text { EF } \\
\text { gha/fö }\end{array}$ \\
\hline Nagyszekeres & Alcsútdoboz & 1 & 347,72 & 88669,53 & 8,42 & 2,11 \\
\hline Mándok & Kápolnásnyék & 1 & 333,80 & 85119,52 & 8,09 & 2,02 \\
\hline Beregdaróc & Sóskút & 1 & 330,85 & 84366,31 & 8,01 & 2,00 \\
\hline Szatmárcseke & Bugyi & 1 & 326,13 & 83162,27 & 7,90 & 1,98 \\
\hline Nyírlövő & Kápolnásnyék & 1 & 325,87 & 83097,72 & 7,89 & 1,97 \\
\hline Tyukod & Piliscsaba & 1 & 324,48 & 82742,29 & 7,86 & 1,97 \\
\hline Nagyecsed & Majosháza & 1 & 321,75 & 82045,64 & 7,79 & 1,95 \\
\hline Nagyhódos & Csömör & 1 & 320,24 & 81662,18 & 7,76 & 1,94 \\
\hline Tiszakóród & Budapest & 1 & 320,18 & 81646,12 & 7,76 & 1,94 \\
\hline Császló & Budapest & 1 & 318,31 & 81168,04 & 7,71 & 1,93 \\
\hline \multicolumn{2}{|l|}{ top 10 összesen } & 10,00 & 3269,33 & 833679,62 & 79,20 & \\
\hline \multicolumn{2}{|l|}{ összesen } & 380357,00 & 13253901,10 & 3379744779,31 & 321075,75 & \\
\hline \multicolumn{2}{|l|}{$\%$} & 0,00003 & 0,00025 & 0,00025 & 0,00025 & \\
\hline
\end{tabular}

azok feleltek az ingázásból származó lábnyom $8 \%$-áért. A top 10-ben szereplő viszonylatok mindegyike a budapesti várostérségen belül található. Közülük Budaörs volt az egyetlen település, amely lakóhelyként és munkahelyként is szerepelt a toplistában (4. táblázat).

Valamelyest módosul a települések köre, ha az ökológiai lábnyom nagysága alapján felállított listát vizsgáljuk (5. táblázat). 2011-ben az ingázásból eredő ökolábnyomhoz legnagyobb mértékben hozzájáruló 10 viszonylat volt felelős az ökológiai lábnyom 10\%-áért. A két táblázat összevetéséből nyilvánvalóvá válik, hogy a budapesti városrégión belül Érd, Dunakeszi és Szigetszentmiklós szerepe kiemelkedő az ingázásban és az ezzel járó ökológiai lábnyomban. A legnagyobb egyéni ökológiai lábnyommal járó viszonylatok mindössze 1-1 foglalkoztatottat érintenek. Sajnálatos módon ezeknél a viszonylatoknál az ingázásból származó ökológiai lábnyom akár tízszerese is lehet az átlagosnak (2,1 gha) (6. táblázat).

Az ingázás okozta ökolábnyom feltárása után fölmerül a kérdés, hogy a Budapesten müködő autómegosztó és telekocsi rendszerek milyen szerepet játszhatnak, és milyen potenciállal rendelkezhetnek a közlekedés és az ingázás okozta ökológiai lábnyom csökkentésében, illetve valós alternatívát jelentenek-e a személyes autóhasználattal szemben?

\section{AZ AUTÓMEGOSZTÓ ÉS TELEKOCSI RENDSZEREK A BUDAPESTI VÁROSRÉGIÓBAN}

A legtöbb ingázót érintő viszonylatokra végzett vizsgálataink szerint a telekocsi rendszerek szerepe napjainkban elhanyagolható. Pilotkutatásunkban a két legismertebb szolgáltató, az Oszkár és a BlaBlaCar hirdetésmegosztó rendszerét vizsgáltuk (7. táblázat). Látható, hogy a BlaBlaCar elhanyagolható szerepet tölt be a várostérség ingázásában, amiben annak is szerepe lehet, hogy a piacvezető Oszkárnál lényegesen később jelent meg a hazai piacon. Nemzetközi szinten viszont a BlaBlaCar a piacvezető platformok közé tartozik, így a környezetre gyakorolt pozitív hatásai közismertek. A BSDC (2017) jelentése szerint a BlaBlaCar szolgáltatások igénybevételének köszönhetően 2 év alatt 1 millió tonnával csökkent a globális szén-dioxid kibocsátás. 


\begin{tabular}{|c|c|c|c|c|c|}
\hline & & \multicolumn{2}{|c|}{ Oszkár } & \multicolumn{2}{|c|}{ BlaBla car } \\
\hline & & $\begin{array}{c}\text { aktív } \\
\text { hirdetések }\end{array}$ & $\begin{array}{c}\text { napi átlagos } \\
\text { hirdetések } \\
\text { száma }\end{array}$ & $\begin{array}{c}\text { aktív } \\
\text { hirdetések }\end{array}$ & $\begin{array}{c}\text { napi átlagos } \\
\text { hirdetések } \\
\text { száma }\end{array}$ \\
\hline Érd & Budapest & 78 & 2 & nincs & \\
\hline Dunakeszi & Budapest & 357 & 7 & nincs & \\
\hline Budapest & Budaörs & 333 & 5 & nincs & \\
\hline $\begin{array}{l}\text { Szigetszent- } \\
\text { miklós }\end{array}$ & Budapest & 301 & 7 & nincs & \\
\hline Budaörs & Budapest & 43 & 1 & nincs & \\
\hline Gyál & Budapest & 146 & 3 & nincs & \\
\hline Szentendre & Budapest & 335 & 6 & nincs & \\
\hline Vecsés & Budapest & 44 & 1 & 8 & 1 \\
\hline Fót & Budapest & 120 & 3 & nincs & \\
\hline Dunaharaszti & Budapest & 48 & 2 & nincs & \\
\hline
\end{tabular}

Forrás: Oszkár, BlaBlaCar

\begin{tabular}{|c|c|c|c|}
\hline & & átlagár Oszkár (Ft) & $\begin{array}{c}\text { átlagár } \\
\text { vonattal }(\mathrm{Ft})\end{array}$ \\
\hline Érd & Budapest & 500 & 465 \\
\hline Dunakeszi & Budapest & $200-600$ & 310 \\
\hline Budapest & Budaörs & $100-400$ & 250 \\
\hline Szigetszentmiklós & Budapest & $200-650$ & nincs \\
\hline Budaörs & Budapest & 250 & 250 \\
\hline Gyál & Budapest & $300-850$ & 465 \\
\hline Szentendre & Budapest & $300-1000$ & 310 (HÉV) \\
\hline Vecsés & Budapest & 200 & 465 \\
\hline Fót & Budapest & $300-500$ & 370 \\
\hline Dunaharaszti & Budapest & $299-500$ & 465 \\
\hline
\end{tabular}

Forrás: szolgáltatók honlapjai (oszkar.com, mavstart.hu)

latban napi szinten Kecskemét-Budapest (17 hirdetés), GyőrBudapest (30 hirdetés) és Miskolc-Budapest (50 hirdetés) viszonylatokban tölt be jelentősebb szerepet a telekocsi rendszer, vagyis azokban az esetekben, ha az ingázó a várostérségen kívülről - megyeszékhelyekről, regionális centrumokból ingázik, és nagyobb távolságokat tesz meg (Bálint - Trócsányi 2016). Az autómegosztás azonban nem kizárólag munkába járáshoz, hanem szabadidős programokhoz vagy iskolába járáshoz is használható, így a telekocsi rendszerek tényleges napi hatása az ingázás terén feltehetőleg még ennél is kisebb. Meg kell említenünk viszont azt is, hogy az utazásmegosztás egy része nem hivatalos platformokon keresztül történik, hanem munkatársak, barátok közvetlen megegyezésén keresztül zajlik, így ezek nem jelennek meg a hivatalos adatbázisokban. Abban, hogy a teleko-

A budapesti városrégióban a top 100 viszonylatban 196294 fó ingázik, viszont a napi szinten meghirdetetett telekocsi hirdetések átlagos száma csak 330 körül alakul. Egy autóban jellemzően 3 helyet hirdetnek meg. A top 100 viszonylat közel kétszázezer ingázójára ez napi szinten csak mintegy 1000 helyet jelent. A 100 legtöbb ingázót érintő viszony- csi rendszerek rövid távon kevésbé versenyképesek, mint hosszú távon, az árszínvonalnak fontos szerepe van. Míg hosszú távon a telekocsi rendszer jelentős költségmegtakarítást jelenthet (jóval olcsóbb, illetve megbízhatóbb és gyorsabb, mint az állami kézben lévő személyszállítás), az árelöny rövid távon nem számottevő (8. táblázat). 
Az autómegosztás (car-sharing) Magyarországon egyedül Budapesten működik és egyelőre gyerekcipőben jár, mert az ingázásra is hatást gyakorló autómegosztók (mint pl. a Car2Go) még nem jelentek meg. A carsharing terén az első lépéseket az Avalon cég tette meg 2011-ben, majd 2016-ban követte öt a GreenGo, végül 2018-ban a MOL Limo is beszállt szolgáltatásával. Ezen szolgáltatások egyelőre csak Budapest belső területein elérhetők, így az ingázásban nem játszanak szerepet. Ugyanakkor hosszú távon kiemelkedő szerepük lehet a nagyvárosi közlekedés modernizálásában és az autóforgalom okozta környezetszennyezés csökkentésében. Ennek különösen olyan belvárosi útszakaszokon lehet pozitív hozadéka, amelyeken jelentős jármüforgalom zajlik.

Az autómegosztó és telekocsi rendszerek pozitív környezeti hatása nem elhanyagolható. Az MIT (2016) becslése szerint a jól müködő ridesharing rendszerek akár 30\%-kal is csökkenthetik a jármüforgalmat a nagyvárosokban. Öt észak-amerikai városra (Calgary, San Diego, Seattle, Vancouver és Washington D.C.) kiterjedő vizsgálat eredményei szerint az autómegosztásból származó kibocsátáscsökkentő hatás nagyobb mértékű, mint a kibocsátást növelő tényezők hatása, és éves szinten háztartásonként 0,84 t $\mathrm{CO}_{2}$ csökkenést (vagyis az ökológiai lábnyom 0,21 gha-os csökkenését) eredményezik (Marteen - Shaheen, 2011). A jelenlegi szerény volumen ellenére a különböző autómegosztó és telekocsi rendszerek a budapesti városrégióban is jelentősen csökkenthetnék a szén-dioxid kibocsátást, és ily módon komolyan hozzájárulhatnának a nagyvárosok környezeti állapotának javulásához. Ezen lehetőségek nagyobb kiaknázása föleg annak ismeretében lenne szükséges, hogy Budapest városfejlesztési politikájában kitüntetett szerepet játszik a közlekedés és a környezetvédelem helyzetének javítása. Ebből a szempontból azt lenne érdemes mérlegelni, hogy az autómegosztó szolgáltatásokat a belső kerületekből hogyan lehetne kiterjeszteni a városrégió tágabb területére, illetve a telekocsi szolgáltatásokat hogyan lehetne hatékonyabban kihasználni a hosszú távú ingázásban és a rövid távú viszonylatokon.

\section{7. ÖSSZEFOGLALÁS}

A szakirodalmi áttekintés rávilágított arra, hogy a közösségi gazdálkodás átalakítja és felborítja a régóta működő, klasszikus üzleti gyakorlatokat. A tradicionális fogyasztói attitüdöt és magatartást a fogyasztási hálózatok és mintázatok irányába tereli, amelyekben a tulajdonlás helyébe az elérhetőség és a hozzáférhetőség lép. A megosztott fogyasztásnak ily módon komoly szerepe lehet a túlfogyasztás csökkentésében, a szegények helyzetének javításában, illetve a környezeti problémákkal és klímaváltozással összefüggő kérdések megoldásában.

Az európai közösségi gazdaságban a carsharing és car-pooling szolgáltatások szerepe és volumene dinamikusan nö, s a közeljövöben ezen a téren Európa-szerte jelentős piaci bővülés várható. A nemzetközi tapasztalatok emellett azt mutatják, hogy a telekocsi rendszereknek, az autómegosztásnak vagy a kötöttpályás közlekedésnek kiemelt szerepe lehet az ökológiai lábnyom és végső soron a közlekedés negatív környezeti hatásainak csökkentésében. Adta magát a kérdés, hogy milyen folyamatok játszódnak le ezen a téren a budapesti városrégióban?

A témakör feldolgozása során első körben feltártuk az ingázásból eredő ökológiai lábnyom meghatározó viszonylatait Budapest városrégiójában, vagyis meghatároztuk azokat az ingázási útvonalakat, amelyek a legnagyobb mértékben járulnak hozzá az ökológiai lábnyomhoz. A budapesti városrégióban regisztrált 14740 ingázási viszonylatból a legtöbb ingázót érintő első 100 viszonylat az összes ingázó több mint 50\%-át tömöríti és ezen viszonylatok felelősek az ingázásból származó ökológiai lábnyom 38\%-áért. Az ingázás és az ebből eredő környezeti nyomás tehát nagyon koncentráltan jelenik meg a városrégióban.

A továbbiakban arra a kérdésre kerestük a választ, hogy a sharing economy közlekedéssel összefüggő szolgáltatásai, vagyis a carpooling és a car-sharing hogyan és milyen mértékben képesek csökkenteni a Budapestre nehezedő környezeti nyomást. Eredmé- 
nyeink arról tanúskodnak, hogy a telekocsi rendszerek szerepe a kis távolságok miatt elhanyagolható, a free-floating rendszerek jelenleg csak a város határain belül müködnek és a klasszikus autómegosztók szolgáltatási területe sem terjed ki az egész várostérségre. A sharing economy közlekedéssel öszszefüggő szolgáltatásai tehát egyelöre nem veszélyeztetik a tradicionális utazási és szállítási formák egyeduralmát. Budapesten a szolgáltatások elterjedését a hosszabb távú, várostérség határait átlépő utazások esetében az anyagi tényezők (költséghatékonyság és olcsó utazás), míg a rövid távú utazások esetében a társadalmi és szociális tényezők (környezettudatos életmód, közösségi fogyasztás) hajthatják előre.

A budapesti városrégió területén a telekocsi és autómegosztó rendszerek a jövőben - átgondolt város- és közlekedésfejlesztési koncepció esetén - eredményesen járulhatnának hozzá a közlekedés okozta logisztikai és környezeti problémák csökkentéséhez, ezért fontos lenne ennek a pillérnek a kiépítése. Ehhez nélkülözhetetlen lenne olyan városfejlesztési lépések megtétele, illetve állami vagy önkormányzati támogatási rendszerek kidolgozása, amelyek lehetővé teszik Budapest számára a közösségi gazdaság adaptálását és fejlődését.

\section{KÖSZÖNETNYILVÁNÍTÁS}

A tanulmány a Nemzeti Kutatási, Fejlesztési és Innovációs Hivatal (HKFIH/OTKA) K119710 és K128717 sz. kutatási projektjeinek támogatásával készült.

\section{FELHASZNÁLT IRODALOM}

[1] Anielski, M. (2010): Edmonton's Ecological Footprint. The Edmonton Sustainability Papers 12.

[2] Bálint, D. - Trócsányi, A. (2016): New ways of mobility: the birth of ridesharing. A case study from Hungary. Hungarian Geographical Bulletin 65(4): 391-405. DOI: http://doi.org/c2gt

[3] Becker, H. - Loder, A. - Smid, B. Axhausen, K-W. (2017a): Modeling carsharing membership as a mobility tool:
A multivariate Probit approach with latent variables. Travel Behaviour and Society 8():26-36. DOI: http://doi.org/c28d

[4] Belk, R. (2014): You are what you can access: Sharing and collaborative consumption online. Journal of Business Research 67(8):1595-1600. DOI: 10.1016/j. jbusres.2013.10.001

[5] Bessenyei, Gy (2014): Városi mobilitás - Közösségi megoldások. Közlekedéstudományi Szemle. 54 (1) 24-28.

[6] Botsman, R. - Rogers, R. (2010): What's mine is yours: the rise of collaborative consumption. First edition, HarperCollins Publishers, New York.

[7] Braun, A. (2017): Car-less or car-free? Socioeconomic and mobility differences among zero-car households. Transport Policy 60.():152-159. DOI: http://doi.org/ gcpcfm

[8] BSDC (2017): Better Business Better World. The report of the Business \& Sustainable Development Commission. http:// report.businesscommission.org/uploads/ BetterBiz-BetterWorld_170215_012417.pdf

[9] Conner-Simons, A. (2016): Study: Carpooling apps could reduce taxi traffic 75\%. News. Retrieved from https://www. csail.mit.edu/ridesharing_reduces_ traffic_300_percent

[10] Deloitte (2017): Car Sharing in Europe Business Models, National Variations and Upcoming Disruptions. https://www2. deloitte.com/content/dam/Deloitte/de/ Documents/consumer-industrial-products/ CIP-Automotive-Car-Sharing-in-Europe. pdf

[11] Deloitte (2016): Economic effects of ridesharing in Australia. Retrieved from https://www2.deloitte.

[12] Felländer, A. - Ingram, C. - Teigland, R. (2015): Sharing economy - Embracing change with caution. Näringspolitiskt Forum Rapport 11. 70 p. http://eng. entreprenorskapsforum.se/2015/08/21/ sharing-economy-embracing-change-withcaution

[13] Ferrero, F. - Perboli, G. - Rosano, M. Vesco, A. (2018): Car- sharing sevices. An annoted review. Sustainable Cities and Society 37():501-518. DOI: http://doi.org/c28f 
[14] Friedman, G. (2014): Workers without employers: shadow corporations and the rise of the gig economy. Review of Keynesian Economics, 2 (2) 171-188.DOI: http://doi.org/gckft5

[15] Frost \& Sullivan (2010): Car sharing: Driving the way to a greener future. http:// www.frost.com/sublib/display-report. do?id=MB41-01-00-00-00

[16] Kiss J. P. - Szalkai G. (2018): Az ingázás mobilitási jellemzői a legutóbbi népszámlálások adatai alapján. Területi Statisztika 58(2): 177-199.

[17] Kovács Z. - Szigeti C. - Egedy T. - Szabó B. - Kondor A. Cs. (2017): Az urbanizáció környezeti hatásai - az ingázás ökológiai lábnyomának változása a budapesti várostérségben. Területi Statisztika 57 (5): 469494.

[18] Marteen, E. - Shaheen, S. (2011): Greenhouse Gas Emission Impacts of Carsharing in North America IEEE Trans. Intell. Transp. Syst. 12. 1074-1086. DOI: http://doi.org/cn2s4n

[19] MIT (2016): https://www.csail.mit.edu/ ridesharing_reduces_traffic_300_percent

[20] MIT (2009): „Real-Time" Rideshare Research 2009: http://ridesharechoices.scripts. mit.edu/home/histstats/

[21] Perboli, G. - Ferrero, F. - Musso, S. Vasco, A. (2017): Business modell and tariff simulation in carsharing services. Transportation Research.Part A 115():3248 DOI: http://doi.org/gcsjsm

[22] Petrini, M. - Freitas, C. S. de. - Silveira, L. M. da S. 2017: A Proposal for a Typology of Sharing Economy. Revista de Administração Mackenzie, 18(5):39-62.

[23] PWC (2016): Shared benefits. https://www. pwc.co.uk/issues/megatrends/collisions/ sharingeconomy/future-of-the-sharingeconomy-in-europe-2016.html
[24] Richardson, L. (2015): Performing the sharing economy. Geoforum, 67: 121-129.

[25] Rinne, A. (2017): What exactly is the sharing economy? World Eocnomic Forum. https://www.weforum.org/agenda/2017/12/ when-is-sharing-not-really-sharing

[26] Santoso, A.S. - Nelloh, L.A.M. (2017): User Satisfaction and Intention to Use Peer-toPeer Online Transportation: A Replication Study. Procedia Computer Science 124():379-387. DOI: http://doi.org/c28g

[27] Schmöller, S. - Weikl, S. - Müller, J. Bogenberger, K. (2015): Empirical analysis of free-floating carsharing usage: The Munich and Berlin case. Transportation Research Part C: Emerging Technologies 56():34-51. DOI: http://doi.org/f7hr8m

[28] Schor, J. B. (2014): Great Transition Iniciative. www.greattransition.org/ publication/debating-the-sharing-economy

[29] Szabó, T. - Szabó, B. - Kovács, Z. (2014): Polycentric urban development in postsocialist context: the case of the Budapest Metropolitan Region. Hungarian Geographical Bulletin 63 (3): 287-301. DOI: http://doi.org/9bq

[30] Wallenstein, J. - Shelat, U. (2017): What's next for the sharing economy? BCG Henderson Institute. https://www.bcg.com/ publications/2017/strategy-technologydigital-whats-next-for-sharing-economy. aspx

[31] Wilson J. - Anielski, M. (2015): Saskatoon Ecological Footprint. City of Saskatoon Ecological Footprint Report 2014 https://www.saskatoon. ca/sites/default/files/documents/ corporate-performance/environmentalcorporate-initiatives/communityenvironmental-programs/saskatoon_ef_ city_report_2015_feb_28_2016_final.pdf 


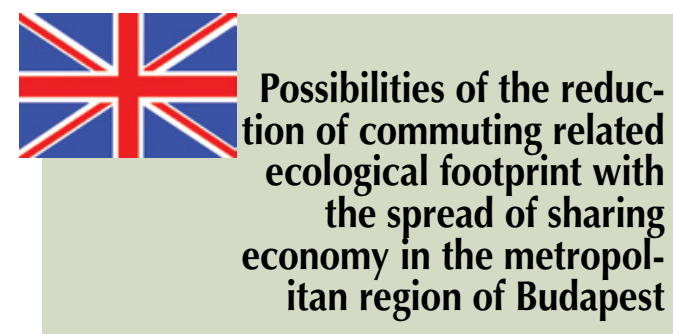

Suburbanization, the concomitant urban sprawl, and the growing concentration of new jobs in suburban centres have inevitably led to increasing commuting in the metropolitan region of Budapest since the change of regime. In the study we aim to answer the question: to what extent alternative means of transport providers of the sharing economy (car-sharing and carpooling) could contribute to lower levels of ecological footprint caused by commuting. Firstly, we summarize the most important experiences of sharing economy related to transport at the national and international levels. Secondly, we present the most important destinations of commuting in the metropolitan region of Budapest and their contribution to the ecological footprint. Finally, we analyse the spatial and temporal characteristics of advertisements gathered from the leading car-pooling platforms and we try to draw the actual role of car-sharing and carpooling in reducing environmental loads.
Möglichkeiten der Reduzierung des pendelverkehrsbezogenen ökologischen Fußabdrucks durch die Verbreitung der Sharing Economy in der Metropolregion Budapest

Die Suburbanisierung und ihre Begleiterscheinung, die Zersiedelung der Stadt und die wachsende Konzentration neuer Arbeitsplätze in den Vorstadtzentren haben seit der politischen Wende in der Metropolregion Budapest zwangsläufig $\mathrm{zu}$ einem zunehmenden Pendelverkehr geführt. In der Studie wollen wir die Frage beantworten, inwieweit alternative Transportmittel der Sharing Economy (Car-Sharing und Car-Pooling) zur Senkung des ökologischen Fußabdrucks von dem Pendelverkehr beitragen können. Erstens fassen wir die wichtigsten Erfahrungen zusammen, die hinsichtlich der Sharing Economy im Verkehrswesen auf nationaler und internationaler Ebene vorliegen. Zweitens es werden die wichtigsten Pendelziele in der Metropolregion Budapest und ihr Beitrag zum ökologischen Fußabdruck vorgestellt. Schließlich analysieren wir die räumlichen und zeitlichen Merkmale der Angebote, die von den führenden Plattformen für Fahrgemeinschaften gesammelt wurden, und versuchen, die tatsächliche Rolle von Car-Sharing und Fahrgemeinschaften bei der Verringerung der Umweltbelastung zu ermitteln.

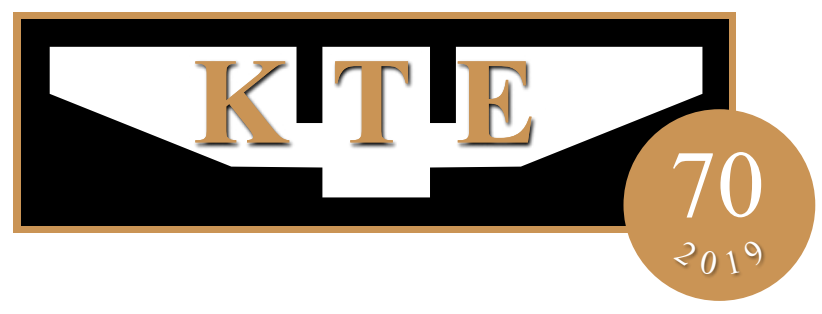




\section{Támogatóink 2018-ban}

\section{KöZÚTI}

KöZL.EKEDÉSBIZTONSÁGI

AKCIÓPROGRAM

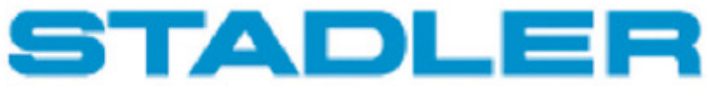

Stadler Trains Magyarország Kft.

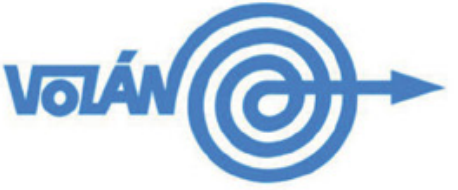

volánbusz

b. HungaroControl

Magyar Légiforgalmi Szolgálat
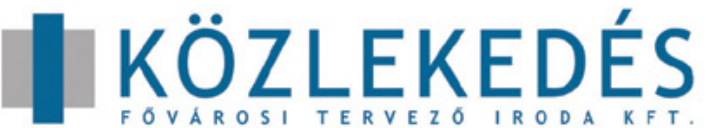

Nemzeti Fejlesztési Minisztérium
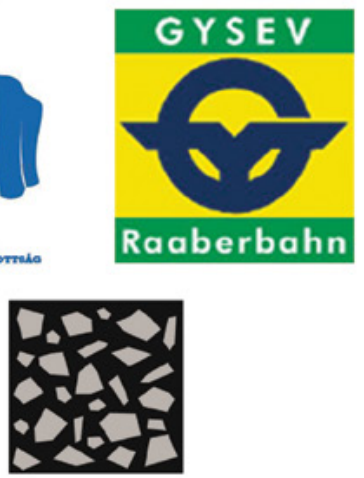

E U R O A S ZFA L T ÉPITOO És SZOLGÁltATÓ KFT.

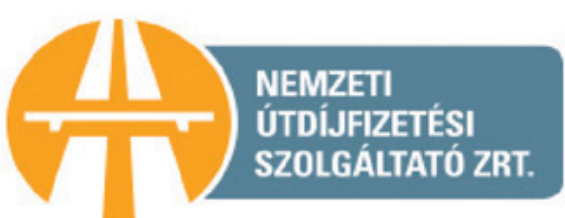

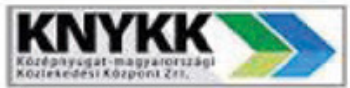

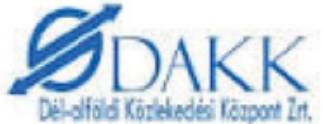

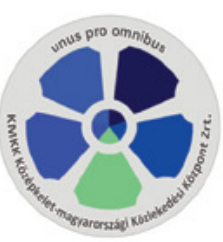
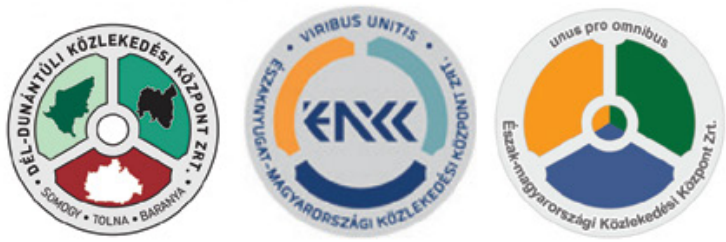
